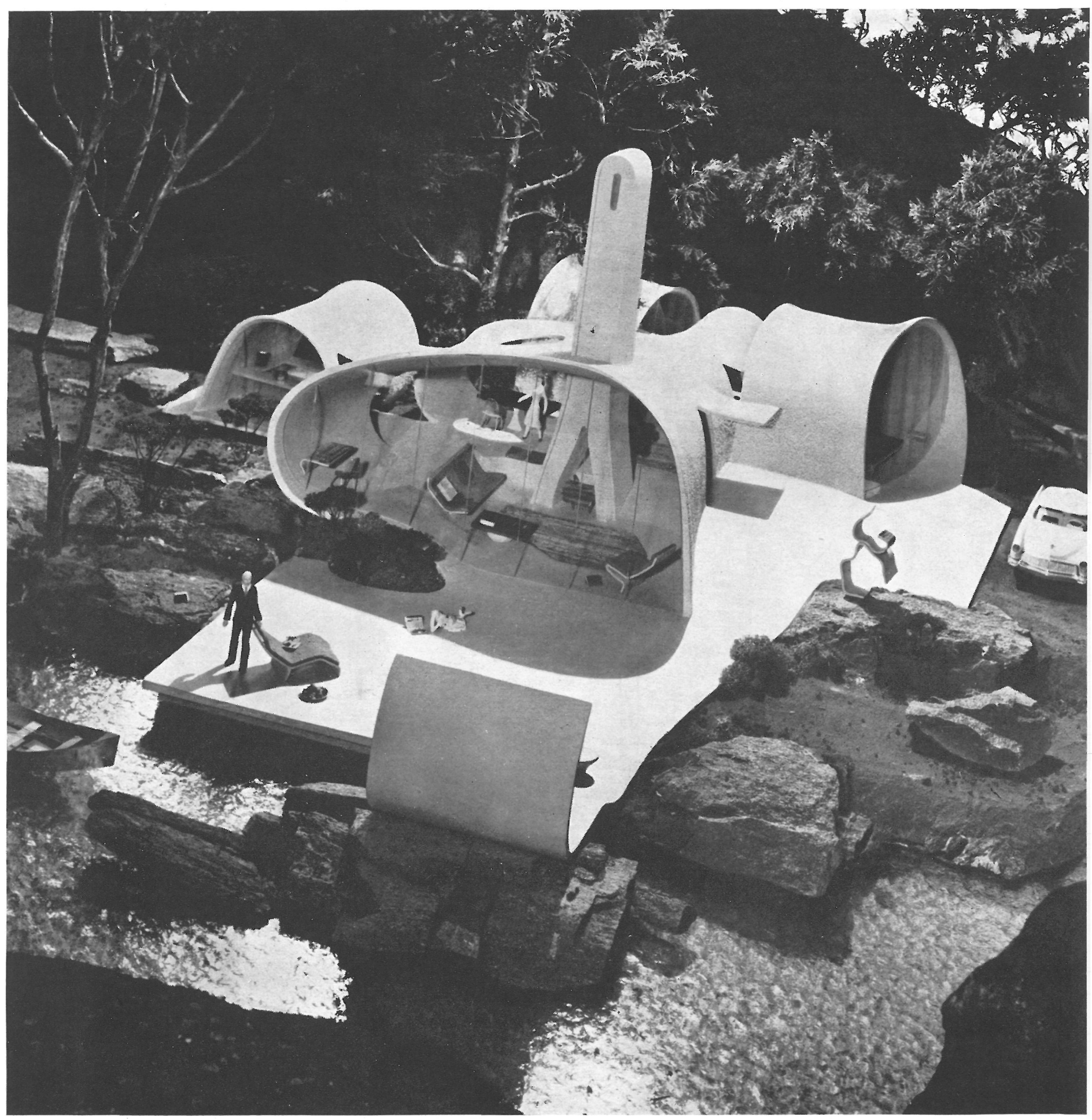

\title{
casa de estructura laminar
}

$161-64$

\section{JOHN MAC L. JOHANSEN, arquifecto y MARIO SALVADORI, ingeniero}

Llevando hasta sus últimos extremos la utilización de las bóvedas laminares de hormigón se ha proyectado esta casa. No se trata de una realización práctica, sino de un estudio teórico y experimental sobre las posibilidades de este tipo de estructuras.

Una casa no es sino un caparazón para guarecerse del frío, del viento, del calor, de la lluvia y de la nieve. Cualquier forma es buena si estas necesidades están cubiertas. El que la solución sea económica dependerá de la lógica organización y mecanización de la construcción y de la industria que atienda las necesidades de la misma.

Y además, a fin de cuentas, una casa es económica cuando la familia que en ella vive es feliz, ya que sólo en estas condiciones aportará un máximo esfuerzo y colaboración a la sociedad que pertenece. 